\title{
Butir-Butir Nilai Pancasila Dalam Kajian Tafsir Mudhu'iy
}

\author{
Ahmad Dibul Amda, Ratnawati, Mirzon Daheri \\ Institut Agama Islam Negeri (IAIN) Curup, Indonesia \\ dibulahmad@gmail.com
}

\begin{abstract}
The attitude opposing Pancasila on one hand rests upon the Qur'an as the legal basis for the people and on the other hand is a consistently hot discourse. The foregoing makes it essential to study the relevance of Pancasila and the Qur'an. The researchers examine the Qur'anic viewpoint on Pancasila by examining its relevance to the values of Pancasila's points. This library research is descriptive qualitative. The researchers use the maudhu'iy tafsir approach in elaborating Qur'anic verses to see their compatibility with Pancasila. Maudhu'iy's interpretation begins by collecting verses related to the problem, analyzing their meanings so that they come to a conclusion. From the research, it can be understood that Pancasila and the Qur'an have the same intentions and meaning relationships. In principle, Pancasila is the Islamic teaching in the Qur'an. This conclusion is indicated by the 45 points of Pancasila's values in that all of which have relevant meanings to the Qur'an.
\end{abstract}

Keywords: Pancasila, al-Quran, Meaning, Interpretation of Maudhu'iy

\begin{abstract}
Abstrak
Adanya sikap mempertentangkan Pancasila di satu sisi dengan al-Quran sebagai dasar hukum bagi umatnya di sisi lain, menjadi diskursus yang terus hangat. Hal ini menjadikan kajian relevansi Pancasila dengan al-Quran penting dilakukan. Peneliti mengkaji sudut pandang al-Quran terhadap terhadap Pancasila dengan menilik relevansinya dengan nilai butir-butir Pancasila. Penelitian kepustakaan ini, bersifat deskriptif kualitatif. Peneliti menggunakan pendekatan tafsir maudhu'iy dalam mengelaborasi ayat-ayat Al-Quran yang terkait untuk melihat keserasiannya dengan Pancasila. Tafsir maudhu'iy dimulai dengan mengumpulkan ayat-ayat yang berkaitan dengan masalah, menganalisa maknanya sehingga mendapat kesimpulan. Dari penelitian dapat dipahami bahwa Pancasila dan al-Quran memiliki hubungan makna dan maksud yang sama. Pancasila secara prinsip merupakan ajaran Islam yang ada di al-Quran. Simpulan ini ditunjukkan dengan 45 butir nilai Pancasila yang kesemuanya memiliki relevansi makna dengan al-Quran.
\end{abstract}

Kata Kunci: Pancasila, al-Quran, Makna, Tafsir Maudhu'iy

FOKUS : Jurnal Kajian Keislaman dan Kemasyarakatan Vol. 5, No. 2, 2020

LPPM Institut Agama Islam Negeri (IAIN) Curup - Bengkulu

p-ISSN 2548-334X, e-ISSN 2548-3358

DOI: $10.29240 /$ jf.v5i2.1666 | p. 171-196 


\section{Pendahuluan}

Pancasila menjadi dasar negara diawali kesepakatan Panitia Persiapan Kemerdekaan Indonesia (PPKI). Makanya, Pancasila tercantum dalam pembukaan Undang Undang Dasar Negara Indonesia tahun 1945 dalam alinea keempat sebagai dasar negara Republik Indonesia. Selanjutnya, Pancasila dipertegas sebagai pandangan hidup bangsa yang telah dimurnikan melalui Memorandum Dewan Perwakilan Rakyat (DPR) - Gotong Royong 9 Juni $1966 .{ }^{1}$

Dengan demikian, Pancasila menjadi dasar dan ideologi negara adalah kesepakatan politik bangsa Indonesia melalui para pendirinya (founding fathers). Namun, deviasi dalam aktualisasi nilai-nilainya terus terjadi, baik pengurangan, penambahan bahkan penyimpangan. Terus juga ada upaya mengarahkan kembali pandangan pada kesejatian nilai-nilai Pancasila. ${ }^{2}$ Pancasila terus eksis sebagai pemersatu bangsa Indonesia.

Eksistensi Pancasila ini menjadi sangat penting bagi keutuhan Indonesia sebagai negara bangsa. ${ }^{3}$ Terlebih dengan kondisi Indonesia yang multikultur membutuhkan Pancasila sebagai pengayom semua heterogenitas bangsa ini. ${ }^{4}$ Inilah urgensi Pancasila sebagai dasar negara bagi bangsa Indonesia.

Dengan demikian, nilai-nilai Pancasila menjadi sangat penting untuk dipertahankan. Internalisasi nilai-nilai ini pada setiap elemen anak bangsa menjadi usaha yang perlu terus digiatkan. Salah satunya dengan menetapkan nilai-nilai Pancasila yang lebih rigit untuk dapat dihayati dan diamalkan. Hal

${ }^{1}$ Gesmi and Hendri, Buku Ajar Pendidikan Pancasila (Ponorogo: Uwais Inspirasi Indonesia, 2018), 44.

${ }^{2}$ Wayan Tagel Eddy, “Aktualisasi Nilai Pancasila Dalam Kehidupan Berbangsa Dan Bernegara," DHARMASMRTI Nomor, vol. 18, 123-116, accessed August 21, 2020, http://ejournal.unhi.ac.id/index.php/dharmasmrti/article/view/108.

${ }^{3}$ Abdul Hamid Tome, "Evaluasi Norma Kedaulatan Rakyat Dalam Konstitusi Dan Pelaksanaannya Dalam Kerangka Negara Hukum Demoratis," Jurnal.Umt.Ac.Id, accessed August 21, 2020, https://doi.org/10.31332/aladl.v13i1.1717; Abdul Hamid Tome, "Membumikan Pancasila: Upaya Pelembagaan Nilai Pancasila Dalam Kehidupan Masyarakat Desa," Researchgate.Net, 131-118, accessed August 21, 2020 , https://doi.org/10.31332/aladl.v13i1.1717.

${ }^{4}$ Hayati Mardliyah, "Dakwah Multikultural Kh. Ahmad Mustofa Bisri (Gus Mus) Skripsi Diajukan Untuk Memenuhi Sebagian Syarat" (Semarang, 2018), 63, http://eprints.walisongo.ac.id/8484/. 
inilah yang melahirkan Ketetapan MPR-RI Nomor II/MPR/1978 disempurnakan dan dituangkan dalam TAP-MPR-RI NO.I/MPR/2003.

Bertolak belakang dengan upaya itu, sebagian kelompok terus berupaya menghadirkan dasar negara yang berbeda. Salah satunya dengan usaha reeksistensi Piagam Jakarta, ${ }^{5}$ mengkampanyekan ideologi transnasional, ${ }^{6}$ dan hal lain-lain yang berpotensi mendorong disintegrasi bangsa. Hal inilah yang digusarkan pemerintah dalam rakornas Wawasan Kebangsaan dan Ketahanan Nasional, Rabu (17/10/2017). ${ }^{7}$ Bahkan sebahagian umat islam dari mayoritas masyarakat bangsa Indonesia pun tidak jarang sepertinya meragukan kebenaran nilai-nilai yang dikandung oleh Pancasila Dasar Negara Indonesia tersebut, antara lain seperti kelompok umat Islam Hizbut Tahrir dengan konsep khilafahnya. Budi Gunawan sebagai Kepala Badan Intelijen Negara menyatakan Hizbut Tahrir Indonesia (HTI) adalah organisasi lintas negara atau transnasional berupaya menggusur Pancasila sebagai dasar negara Indonesia. ${ }^{8}$

Lebih lanjut ia menjelaskan, bahwa HTI menjelaskan konsep kekhilafaan melalui wesbsite resmi mereka yang kemudian di blokir Kementerian Komunikasi dan Informatika. Dalam artikel berjudul "Apa itu Khilafah?" disebutkan bahwa "khilafah merupakan kepemimpinan umum bagi seluruh kaum Muslim di dunia, dengan menerapkan hukum Islam”"

Artinya upaya untuk menginternalisasikan nilai-nilai Pancasila penting terus dilakukan. Namun, nilai-nilai ini perlu pemahaman yang benar sesuai

\footnotetext{
${ }^{5}$ Chafid Wahyudi, "Realitas Civil Religion Realitas Civil Religion Dalam Pergulatan Politik Islam Indonesia," Proceeldings.Kopertais4.or.Id, 2019, http://proceedings.kopertais4.or.id/index.php/ancoms/article/view/243; Amin Farih, "Konsistensi Nahdlatul Ulama'dalam Mempertahankan Pancasila Dan Kedaulatan Negara Kesatuan Republik Indonesia Di Tengah Wacana Negara Islam," Jurnal Politik Walisongo, 2019, 20-21, https://core.ac.uk/download/pdf/267896206.pdf.

${ }^{6}$ Septiana Chandra Dewi, “Upaya BNPT Dalam Menghadapi Ancaman Keamanan Dari Kelompok Radikal Isis (Islamic State Of Iraq And Syria)," EJournal Ilmu Hubungan Internasional 6, no. 1 (2018): 313-28, www.m.republika.co.id:2014.

${ }^{7}$ Moh. Nadlir, "Mendagri: Masih Ada Ormas Dan Perorangan Yang Ingin Ganti Pancasila," Kompas, October 2017, https://nasional.kompas.com/read/2017/10/18/11051731/mendagri-masih-ada-ormas-danperorangan-yang-ingin-ganti-pancasila?page=all.

8 Prima Gumilang, "Kepala BIN: HTI Ingin Ganti Pancasila Jadi Khilafah," CNN Indonesia, May 12, 2017, https://www.cnnindonesia.com/nasional/20170512135522-12214314/kepala-bin-hti-ingin-ganti-pancasila-jadi-khilafah.

${ }^{9}$ Gumilang.
} 
dengan i'tikad baik para penggagas konsep nilai-nilai Pancasila. Selain itu, perlu upaya menilik pertentangan Pancasila dengan nilai-nilai agama yang seringkali dipertentangkan. Benarkah ada pertentangan keduanya? Dalam Islam dasar hukum bagi para penganutnya adalah al-Quran dan Hadist nabi. Al-Quran berdiri sebagai dasar hukum tertinggi karena ia merupakan kitab suci kalam Allah sebagai Tuhan. Untuk itulah melihat keselarasan atau mungkinkah ada pertentangan antara Pancasila sebagai dasar hidup bernegara dan al-Quran sebagai dasar hidup beragama menjadi penting. bagamaina sebenarnya butir-butir nilai Pancasila tersebut ditinjau dari sudut pandang tafsir al-Quran? Bagaimana relevansi butir-butir tersebut dengan al-Quran?

Penelitian ini adalah penelitian kepustakaan (Library Research). Objek material dari penelitian ini adalah ayat-ayat kitab suci Al-Quran. Penelitian ini menyusun dan mencari data dan teori tentang persepsi Al-Quran tehadap nilai-nilai butir-butir Pancasila termasuk juga buku-buku atau literatur dan karya tulis para tokoh yang relevan sebagai sumber data.

Penelitian ini bersifat deskriptif kualitatif, menekankan makna dalam meninterpretasi data. Salah satu karakteristiknya adalah analisis data yang bersifat induktif/kualitatif . ${ }^{10}$

Pendekatan yang digunakan dalam penelitian ini adalah teori tafsir dengan metode Maudhu'iyy (tematik), karena data-data yang terkumpul akan dianalisis dengan teori tafsir maudhu'iy. Tafsir maudhu'iy adalah penafsiran dengan menghimpun ayat-ayat Al-Quran yang relevan dengan masalah untuk mendapatkan solusi. ${ }^{11}$ Dengan metode maudhu'iy, penafsir secara khusus meneliti ayat-ayat dari berbagai aspeknya, dan melakukan analisa berdasar ilmu alat menafsirkan. Harapannya didapatkan sari dari maksud ayat-ayat tersebut yang berguna memecahkan masalah yang ada. ${ }^{12}$

Dalam penerapan metode tafsir maudhu'iy, Abdul Hay Al-Farmawiy merumuskan beberapa langkah sebagai berikut yakni "Menetapkan masalah yang akan dibahas (topik), menghimpun ayat-ayat yang berkaitan dengan masalah tersebut, menyusun runtutan ayat sesuai dengan masa turunnya, 2008), 9 .

${ }^{10}$ Sugini, Metode Penelitian Kuantitatif, Kualitatif Dan $R \& D$ (Bandung: Alfabeta,

${ }^{11}$ M. Quraish Shihab, Membumikan Al-Quran. Fungsi Dan Peran Wahyu Dalam Kehidupan Masyarakat (Bandung: Mizan, 2007), 111-110.

${ }^{12}$ Abd.Al-Hayy Al-Farmawi, Metode Tafsir Maudhu'iyy; Suatu Pengantar (Jakarta: Raja Grafindo Persada, 1996), 176. 
disertai pengetahuan tentang Asbab al-Nuzulnya, memahami korelasi ayatayat tersebut dalam surahnya masing-masing, menyusun pembahasan dalam kerangka yang sempurna (out line), melengkapi pembahasan dengan haditshadits yang relefan dengan pokok bahasan, mempelajari ayat-ayat tersebut secara keseluruhan dengan jalan menghimpun ayat-ayatnya yang mempunyai pengertian yang sama, atau mengkompromikan antara yang 'am (umum) dan yang khas (khusus), mutlaq dan muqaiyad (terikat), atau yang pada lahirnya bertentangan, sehingga kesemuanya bertemu dalam satu muara, tanpa perbedaan atau pemaksaan"13

Catatan penting dari langkah-langkah tersebut sebab nuzul tidak dinafikkan sebagai sesuatu yang penting dalam memahami ayat al-Quran. Meskipun tidak dimasukkan dalam uraian ia tetap menjadi pertimbangan dalam memahami ayat al-Quran. Begitu juga hubungan antara ayat meski tidak dicantumkan namun tetap menjadi perhatian dalam upaya penafsiran. ${ }^{14}$

Pertimbangan penetapan teori Tafsir Metode Maudhu'iyy sebagai objek formal dalam menganalisis data dalam penelitian ini, diyakini sangat tepat karena data yang dianalisis adalah kata-kata dari ayat-ayat Al-Quran yang mengindikasikan pada satu tema (Maudhu'). Sekalipun demikian disiplin ilmu pengetahuan lain yang dianggap dapat membantu, seperti ilmu filsafat, tasawuf, bahasa Arab dan lain-lain yang relevan tetap digunakan.

Metode Maudhu'iy memiliki berbagai kelebihan sebagaimana dijelas Sayuti. ${ }^{15}$ Salah satu hal utamanya adalah menjadikan al-Quran dinamis dalam menjawab tantangan zaman meskipun tentu memiliki berbagai kekurangan yang juga layak menjadi perhatian. ${ }^{16}$

\section{Pancasila Sebagai Dasar Negara Indonesia}

Sejak awal kemerdekaan kedudukan Pancasila yang paling utama yaitu sebagai dasar negara Indonesia. "Kedudukan Pancasila sebagai dasar negara dapat ditemukan dalam berbagai landasan konstitusional yang pernah berlaku

\footnotetext{
${ }^{13}$ Al-Farmawi, Metode Tafsir Maudhu'iyy; Suatu Pengantar.

${ }^{14}$ Shihab, Membumikan Al-Quran. Fungsi Dan Peran Wahyu Dalam Kehidupan Masyarakat, 177.

${ }^{15}$ Jalâl al-Din Al-Suyûthî, Al-Itqân Fî̀ 'Ulûm Al-Qur'ân (Kairo: Dâr al-Turâth, 1985), 18.

${ }^{16}$ Nashruddin Baidan, Metodologi Penafsiran Al-Quran (Jakarta: Pustaka Pelajar, 1988), 168-165.
} 
di Indonesia". ${ }^{17}$ "Pancasila sebagai dasar negara mengandung makna bahwa nilai-nilai Pancasila dijadikan sebagai landasan dasar dalam penyelenggaraan negara. Nilai dasar Pancasila bersifat abstrak dan normatif. Pancasila sebagai dasar negara berarti seluruh pelaksanaan dan penyelenggaraan pemerintahan harus mencerminkan nilai-nilai Pancasila dan tidak boleh bertentangan dengan Pancasila."18 Makna atau peran Pancasila sebagai dasar negara Republik Indonesia menurut Bambang Suteng Sulasmono, ${ }^{19}$ adalah sebagai berikut:

a. Dasar berdiri dan tegaknya negara

Pancasila merupakan tonggak berdirinya negara Republik Indonesia. Sejarah menunjukkan bahwa Pancasila berperan sebagai dasar pembentukan negara Indonesia merdeka. Pancasila diharapkan dapat menjadi landasan bagi pengelolaan Negara Kesatuan Republik Indonesia. Pancasila harus dijadikan dasar dalam setiap kegiatan bernegara.

b. Dasar kegiatan penyelenggaraan negara

Negara Indonesia didirikan untuk mewujudkan cita-cita dan tujuan nasional bangsa yang dirumuskan dalam Pembukaan Undang Undang Dasar (UUD) 1945. Para penyelenggara negara dituntut untuk memimpin pencapaian tujuan itu. Agar penyelenggaran negara benar-benar dapat mewujudkan tujuan nasional, penyelenggara negara harus mendasarkan semua kegiatan pemerintahan negara kepada Pancasila. Setiap kegiatan penyelenggara negara harus didasarkan dan mempertimbangkan Pancasila sebagai acuan dasar dalam penyelenggaraan negara.

c. Dasar partisipasi warga negara

Warga negara Indonesia mempunyai hak dan kewajiban yang sama untuk mempertahankan negara dan berpartisipasi dalam upaya bersama mencapai tujuan bangsa. Dalam menggunkan hak dan menunaikan kewajibannya itu seluruh warga negara harus berpedoman kepada dasar negara Pancasila. Warga negara harus dapat mengembangkan dan

17 Udiyo Basuki, "Politik Hukum Mahkamah Konstitusi Dalam Membatalkan Konsep Empat Pilar Sebagai Upaya Mendudukkan Pancasila Sebagai Dasar Negara," Supremasi Hukum: Jurnal Kajian Ilmu Hukum, vol. 4, 2015, http://ejournal.uinsuka.ac.id/syariah/Supremasi/article/download/1993/1469.

18 Oksep Adhayanto, "Implementasi Nilai-Nilai Pancasila Sebagai Dasar Negara Dalam Pembentukkan Peraturan Perundang-Undangan," Jurnal Ilmu Hukum, vol. 5, 2015, https://jih.ejournal.unri.ac.id/index.php/JIH/article/view/3599.

${ }^{19}$ B.S Sulasmono, Dasar Negara Pancasila (Sleman: Kanisius, 2015), 68. 
mengamalkan nilai-nilai Pancasila dalam partisipasi upaya mencapai tujuan bangsa Indonesia.

d. Dasar Pergaulan antar warga negara

Pancasila tidak hanya menjadi dasar perhubung antara warga negara dengan negara, melainkan juga dasar perhubungan antar warga negara. Dalam pergaulan sehari-hari tentunya setiap warga negara akan berhubungan dengan warga negara lainnya, dalam hal ini Pancasila dapat dijadikan landasan dasar dalam bergaul dengan warga negara lain.

e. Dasar dan sumber hukum nasional

Seluruh aktivitas penyelenggara negara dan warga negara dalam kehidupan bermasyarakat, berbangsa, dan bernegara haruslah didasarkan pada hukum yang berlaku. Peraturan perundang-undangan atau hukum yang dibentuk untuk penyelengaraan negara harus berdasarkan pada Pancasila. Peraturan yang ada di Indonesia harus sesuai dan tidak boleh bertentangan dengan Pancasila .

Selain sebagai dasar negara, "Pancasila juga (adalah) sebagai ruh dan ideologi Negara Kesatuan Republik Indonesia (NKRI) sampai saat ini masih sangat relevan dan dibutuhkan untuk membangun bangsa yang bermartabat dan punya harga diri di mata dunia". ${ }^{20}$ Beliau juga mengutip kata-kata Bung Karno (Ir. Soekarno) yang dikenal sebagai penggali Pancasila, "Bangsa ini akan mengalami kesulitan besar kalau ideologi Pancasila ditinggalkan". ${ }^{21}$

"Ideologi dalam kehidupan sehari-hari dapat diartikan dengan cita-cita. Cita-cita yang dimaksud adalah cita-cita yang bersifat tetap dan yang harus dicapai, cita-cita tersebut juga dijadikan sebagai dasar atau pandangan hidup. Makna Pancasila sebagai ideologi bangsa adalah bahwa nilai-nilai yang terkandung dalam pancasila menjadi cita-cita normatif penyelenggaraan bernegara. Nilai-nilai yang terkandung dalam Pancasila pada hakikatnya merupakan gambaran bagaimana kehidupan bernegara harus dijalankan. Pancasila sebagai suatu ideologi tidak bersifat kaku dan tertutup, namun

${ }^{20}$ Suryatni, "Pancasila Sebagai Ideologi Negara Dan Hak Asasi Manusia Dalam Menjaga Keutuhan Negara Kesatuan Republik Indonesia," Jurnal Ilmiah Hukum Dirgantara, 2018, 1-18, https://core.ac.uk/download/pdf/288339901.pdf.

${ }^{21}$ Afriadi S Hasibuan and Djoko Sulistyono, "Peranan Ideologi Dalam Integrasi Nasional," Jurnal Kebijakan Pemerintahan 1, no. 1 (2018): 1-10, http://ejournal.ipdn.ac.id/JKP/article/view/1093/633. 
Pancasila dapat bersifat dinamis, reformatif, dan terbuka". ${ }^{22}$

"Pancasila bukanlah sebuah ideologi yang kaku melainkan sebuah ideologi yang fleksibel dan terbuka karena didalam Pancasila memungkinkan serta merangsang pemikiran-pemikiran baru yang inovatif namun tanpa merubah sila-sila yang terkandung di dalamnya. Pancasila sebagai ideologi terbuka". ${ }^{23}$

"Pancasila dapat berperan sebagai pemersatu bangsa, menjaga persatuan dan kesatuan, serta dapat mengarahkan bangsa Indonesia untuk mencapai tujuan yang dicita-citakan. Pancasila dapat memberi gambaran citacita dan dapat dijadikan motivasi dan tekad untuk mencapai cita-cita bangsa Indonesia. Sebagai ideologi, Pancasila juga dapat memberikan tekad untuk menjaga identitas bangsa. Pancasila dapat dijadikan gambaran identitas bangsa, sehingga dengan Pancasila masyarakat dapat mengembangkan karakter dan identitas bangsa Indonesia sendiri. Dalam era globalisasi menjaga identitas bangsa sangat penting unruk dapat menjaga keutuhan bangsa dan dapat menjadikan ciri khas bangsa Indonesia yang berbeda dengan bangsa lain. Pancasila memuat gagasan tentang bagaimana cara mengelola kehidupan bernegara". ${ }^{24}$ Rumusan-rumusan dalam Pancasila tidak langsung operasional maka dari itu harus dilakukan penafsiran ulang terhadap pancasila sesuai perkembangan zaman.

\section{Butir-Butir Nilai Pancasila Dalam Perspektif Al-Quran}

Untuk menemukan bagaimana perspektif al-Quran tehadap butir-butir nilai Pancasila, maka perlu dilakukan penafsiran dan analisis butir-butir nilai Pancasila yang relevan dengan ayat-ayat al-Quran :

Sila Pertama : Ketuhanan Yang Maha Esa

Butir nilai Pertama dari Sila Pertama Pancasila: "Bangsa Indonesia menyatakan kepercayaan dan ketaqwaannya terhadap Tuhan Yang Maha

22 M. Abdul Karim, Menggali Muatan Pancasila Dalam Prespektif Islam (Yogyakarta: Surya Raya, 2004), 68.

23 "Sudarto, Refleksi Metafisik Atas Pancasila, Dalam Jurnal Teologia - Penelusuran Google," Jurnal Filsafat, 1996, 13, https://jurnal.ugm.ac.id/wisdom/article/view/31615/19139.

${ }^{24}$ Mulyono, "Pancasila Sebagai Orthodoksi Dan Orthopraksis Dalam Kehidupan Berbangsa Dan Bernegara," HUMANIKA 23, no. 2 (2016): 40-48. 
Esa"25 sangat relevan dengan QS.al-Ikhlash ayat 1; QS. Al-Maidah 73: Kata (ahad/esa) terambil dari akar kata (وحســ) wahdah yang bermakna kesatuan, demikian juga kata (واحـ) wahid yang bermakna satu. Kata ( (أحـ)ahad bisa berperan sebagai nama dan dapat juga sebagai sifat. Kedudukannya sebagai sifat hanya digunakan untuk menunjukkan Allah SWT. ${ }^{26}$ Dari penafsiran di atas, dapat diketahui bahwa butir nilai Pancasila yang pertama dari Sila pertama, sangat erat hubungannya dengan ayat alQuran surat al-Ikhlash ayat 1 dan Surat al- Maidah ayat 73, karena kata أحسـ berati esa, yaitu Tuhan Yang Maha Esa.

Butir nilai kedua dari sila pertama Pancasila: "Manusia Indonesia percaya dan taqwa terhadap Tuhan Yang Maha Esa sesuai dengan agama dan kepercayaannya masing-masing menurut dasar kemanusiaan yang adil dan beradab"27 sangat relevan dengan QS. Asy-Syura ayat 11 yang menyatakan bahwa Allah Maha Pencipta segala sesuatu yang ada di langit dan bumi. ${ }^{28}$ Dari penafsiran ini, dapat diketahui bahwa butir nilai kedua dari Sila pertama Pancasila. Selanjutnya QS Saba ayat 1: Ayat di atas menyatakan: Segala puji bagi Allah semata dalam kehidupan dunia ini. Dia saja Yang memiliki, menguasai dan mengendalikan apapun yang ada di langit dan di Bumi, karena Dia pula yang memiliki, menguasai dan mengendalikan segala sesuatu yang ada di akhirat nanti. ${ }^{29}$ Jadi dapat diketahui bahwa butir nilai kedua dari Sila pertama Pancasila, juga sangat relevan dengan kedua ayat di atas.

Butir nilai ketiga dari Sila pertama Pancasila: "Mengembangkan sikap hormat menghormati dan bekerjasama antara pemeluk agama dan penganut kepercayaan yang berbeda-beda terhadap Tuhan Yang Maha Esa"30. Sangat

25 BPHN, "Butir-Butir Pancasila," Badan Pembinaan Hukum Nasional, 2014, bphn.go.id > data > documents > butir-butir_pancasila_1\%0A; Kementerian Pertahanan, "45 Butir Pedoman Penghayatan Dan Pengamalan Pancasila," Direktorat Jenderal Perencanaan Pertahanan Kementerian Pertahanan Republik Indonesia, 2014, https://www.kemhan.go.id/renhan/2014/11/20/45-butir-pedoman-penghayatan-danpengamalan-pancasila.html.

${ }^{26}$ M. Quraish Shihab, Tafsir Al-Mishbah, Pesan, Kesan, Dan Keserasian Al-Quran Vol.15 (Jakarta: Lentera, 2002), 716.

27 Kementerian Pertahanan, "45 Butir Pedoman Penghayatan Dan Pengamalan Pancasila"; BPHN, "Butir-Butir Pancasila."

${ }^{28}$ M. Quraish Shihab, Tafsir Al-Mishbah, Pesan, Kesan Dan Keserasian Al-Quran Vol.12 (Jakarta: Lentera Hati, 2002), 12.

${ }^{29}$ Shihab, Tafsir Al-Mishbah, Pesan, Kesan Dan Keserasian Al-Quran Vol.12.

${ }^{30}$ Kementerian Pertahanan, "45 Butir Pedoman Penghayatan Dan Pengamalan Pancasila"; BPHN, "Butir-Butir Pancasila." 
relevan dengan: QS Al-Baqarah 256. Zuhairi berpendapat, bahwa agama tidak dapat dipaksakan. Islam memilih sikap akomodatif dan adaptif tehadap agama-agama dan kebudayaan pada umumnya. Sejatinya tujuan agama adalah menegakan keadilan dan kemanusiaan. Ia menambahkan bahwa pentingnya landasan etis yang kuat dengan tidak membenturkan agama-agama. ${ }^{31}$ QS.Yunus 40-41, menunjukkan betapa Islam tidak memksakan nilai-nilainya bagi seseorangpun, tetapi memberikan kebebasan kepada setiap orang untuk memilih agama dan kepecayaan yang berkenan di hatinya. ${ }^{32}$

Butir nilai keempat dari Sila pertama Pancasila; "Membina kerukunan hidup di antara sesama umat beragama dan kepercayaan terhadap Tuhan Yang Maha Esa"33 sangat relevan dengan QS. Al-Kafirun ayat 1-6; QS. As-Syura 15. Memahami kalimat; La hujjata bainana wa bainakum/tidak ada perdebatan antara kami dan kamu dalam arti tidak perlu ada permusuhan kita karena Tuhan kamu dan Tuhan kami sama dan kita semua adalah hambahamba-Nya sehingga kita tidak perlu bertengkar. ${ }^{34}$

Butir nilai kelima dari Sila pertama : "Agama dan kepercayaan terhadap Tuhan Yang Maha Esa adalah masalah yang menyangkut hubungan pribadi manusia dengan Tuhan Yang Maha Esa" 35 relevan dengan: QS. AlKahfi ayat 29 QS.Ar-Rum 30 Tentang ayat ini (QS. Al-Kahfi ayat 29) tafsir al-Maraghi dijelaskan bahwa sesungguhnya aku tak perlu mengikuti kemauanmu. Dan sesungguhnya aku tak peduli dengan mu atau dengan iman mu. Dan urusan itu terserah kepadamu, daan ditangan Allah lah kemudahan, kekalahan, kejatuhan dan kesesatan. Dia tidak mendapatkan manfaat dari imannya oang beriman, dan takkan mendapat bahaya akibat kekafiran orangorang kafir. ${ }^{36}$ Sementara tafsir QS.Ar-Rum 30 diterangkan bahwa "janganlah termasuk orang-orang yang mempersekutukan Allah dan dari mereka yang memecah belah agama mereka, mengubahnya, merusaknya dan beriman

31 Zuhairi Misrawi, Al-Quran Kitab Toleransi, Inklusivisme, Pluralisme Dan Multikulturalisme (Jakarta: Fitrah, 2007), 253.

${ }^{32}$ M. Quraish Shihab, Tafsir Al-Mishbah, Pesan, Kesan, Dan Keserasian Al-Quran Vol.5 (Jakarta: Lentera, 2002), 411.

33 Kementerian Pertahanan, "45 Butir Pedoman Penghayatan Dan Pengamalan Pancasila."

${ }^{34}$ Shihab, Tafsir Al-Mishbah, Pesan, Kesan Dan Keserasian Al-Quran Vol.12, 136. Pancasila."

${ }^{35}$ Kementerian Pertahanan, "45 Butir Pedoman Penghayatan Dan Pengamalan

${ }^{36}$ Ahmad Mushthafa Al-Maraghi, Tafsir Al-Maraghi (Semarang: Karya Thoha Putra, 1993), 282. 
kepada sebagian isinya, mengingkari sebagian yang lain, masing-masing golongan merasa bangga dengan pendapatnya dan pendiriannya sendiri". ${ }^{37}$

Butir nilai keenam dari Sila pertama Pancasila: "Mengembangkan sikap saling menghormati kebebasan menjalankan ibadah sesuai dengan agama dan kepercayaanya masing masing" ${ }^{38}$ relevan dengan QS. al-Kafirun 1-6. "Surat ini sepenuhnya menyuruh seorang mukmin supaya benar ikhlas kepada Allah dalam semua gerak, langkah dan tutur katanya, dan bebas sama sekali dari segala apa yang menyerupai cara syirik, jika telah berbeda dalam iman keyakinan, maka harus pula berbeda dalam amal perbuatannya". ${ }^{39}$ QS. al-Angkabut 46 "beberapa ahli tafsir berpendapat bahwa ayat ini adalah muhkamah (tidak mansukh) sehingga bagi ahli kitab masih terbuka kesempatan untuk diajak bedebat tentang agama dengan cara yang tebaik".

Butir nilai ketujuh dari Sila pertama: "Tidak memaksakan suatu agama dan kepercayaan terhadap Tuhan Yang Maha Esa kepada orang lain"40 relevansinya dengan QS.al-Baqarah 256. Dalam konteks tafsir ayat ini menegaskan bahwa tidak ada paksaan dalam memasuki agama. Karena iman harus dibarengi dengan perasaan taat dan tunduk. Hal ini tentunya tidak bisa terwujud dengan cara memaksa, tetapi hanya mungkin melalui hujjah atau argumentasi. ${ }^{41}$ Sedangkan QS. Qaf 45 menjelaskan bahwa manusia tidak dapat memaksakan kehendak dengan cara apapun termasuk intimidasi. ${ }^{42}$

\section{Sila Kedua : Kemanusiaan yang Adil dan Beradab}

Butir nilai pertama dari Sila kedua Pncasila: "Mengakui dan memperlakukan manusia sesuai dengan harkat dan martabatnya sebagai makhluk Tuhan Yang Maha Esa"43 relevan dengan: QS al-Mâidah ayat 8. Menurut al-Maraghi bahwa ayat ini memerintahkan manusia untuk berlaku adil dalam berbagai situasi termasuk menjadi saksi. ${ }^{44}$ Hal ini memiliki

\footnotetext{
${ }^{37}$ Ibnu Katsir, Tafsir Ibnu Katsir (Surabaya: Bina Ilmu, 2006), 241.

${ }^{38}$ Kementerian Pertahanan, "45 Butir Pedoman Penghayatan Dan Pengamalan Pancasila."

${ }^{39}$ Ibnu Katsir, Tafsir Ibnu Katsir, 452.

${ }^{40}$ Kementerian Pertahanan, "45 Butir Pedoman Penghayatan Dan Pengamalan Pancasila."

${ }^{41}$ Al-Maraghi, Tafsir Al-Maraghi.

${ }^{42}$ Ibnu Katsir, Tafsir Ibnu Katsir, 381.

${ }^{43}$ Kementerian Pertahanan, "45 Butir Pedoman Penghayatan Dan Pengamalan Pancasila."

${ }^{44}$ Al-Maraghi, Tafsir Al-Maraghi, 51.
} 
kesesuaian dengan QS.al-Isra'33, manun ayat ini lebih cendrung memberikan gambaran tentang kreterian manusia yang beradab seperti bagaimana interaksi social baik sebagai warga masyarakat maupun sebagai warga negara, apalagi di Indonesia yang sangat majemuk ini. ${ }^{45}$

Butir nilai kedua dari sila kedua pancasila: "Mengakui persamaan derajad, persamaan hak dan kewajiban asasi setiap manusia, tanpa membedabedakan suku, keturunan, agama, kepercayaan, jenis kelamin, kedudukan sosial, warna kulit dan sebagainya" ${ }^{46}$ relevan dengan: QS. al-Hujarat 13. Ayat ini menerangkan bahwa manusia itu adalah sama dihadapan Allah, tiada suatu bangsa mempunyai kekebihan dengan yang lain, semuanya adalah sama-sama anak cucu Adam yan membedakan mereka adalah tingkat ketaqwaan saja. ${ }^{47}$ Sedangkan QS.an-Nisa' 1 menegaskan bahwa kesetaraan manusia pada asalnya yang sama yaitu dari Nabi Adam, dengan kesamaan tersebut diharapkan manusia dapat bahu membahu satu sama lain tentu dalam hal yan di ridhai oleh Allah. ${ }^{48}$

Butir nilai ketiga dari Sila kedua Pancasila: "Mengembangkan sikap saling mencintai sesama manusia"49 relevan dengan: QS. al-Mumtahanah 7: ayat menerangkan bahwa boleh jadi yang selama ini menjalin permusuhan diubah oleh Allah menjadi saling mencintai dan menjadi sahabat yang baik. ${ }^{50}$ ayat di atas dipertegas oleh Allah dalam QS. Maryam 96, bahwa Dia akan memberi orang-orang mukmin yang beramal saleh, kecintaan di dalam hati orang banyak. Allah menanamkan kecintaan itu bagi mereka tanpa berpurapura mencintai oang lain dan tidak mencari jalan untuk mendapat kecintaan itu, seperti mengadakan pendekatan, pesahabatann atau berpura-pura berbuat kebaikan. $^{51}$

Butir nilai keempat dari Sila kedua: "Mengembangkan sikap saling

${ }^{45}$ I. Warsah et al., "Muslim Minority in Yogyakarta: Between Social Relationship and Religious Motivation," Qudus International Journal of Islamic Studies 7, no. 2 (2019): 398-367, https://doi.org/10.21043/qijis.v7i2.6873. Pancasila."

46 Kementerian Pertahanan, "45 Butir Pedoman Penghayatan Dan Pengamalan

${ }^{47}$ Ibnu Katsir, Tafsir Ibnu Katsir, 361.

${ }^{48}$ Al-Maraghi, Tafsir Al-Maraghi, 314.

49 Kementerian Pertahanan, "45 Butir Pedoman Penghayatan Dan Pengamalan Pancasila."

${ }^{50}$ Muhammad Nasib Ar Rifaeei, Ringkasan Tafsir Ibnu Katsir (Jakarta: Gema Insani Press, 1999).

${ }^{51}$ Al-Maraghi, Tafsir Al-Maraghi, 152-151. 
tenggang rasa dan tepa selira relevan"52 dengan QS.al-Maidah 2. ayat ini ditafsikan sebagai ayat perintah bertolong-tolongan dalam mengerjakan kabaikan dan takwa, adalah termasuk pokok-pokok petunjuk sosial dalam alQuran. ${ }^{53}$ Sedangkan QS.at-Taubah 71 menjelaskan bahwa di antara kaum muslimin terdapat rasa persaudaraan, kecintaan, saling menolongdan saling mengasihi. ${ }^{54}$

Butir nilai kelima dari Sila kedua Pancasila: "Mengembangkan sikap tidak semena-mena terhadap orang lain relevan"55 dengan: QS.al-Maidah 8. Ayat ini memerintahkan kepada setiap mukmin menegakkan kebenaran dengan penuh keikhlasan baik urusan agama maupun dunia. Sehingga inti dari melaksanakan perintah tersebut adalah kebenaran. ${ }^{56}$ Dalam QS.al-Baqarah 143 juga diterangkan bahwa hendaklah setiap muslim menjadi garda terdepat dalam menjaga kedamaian. ${ }^{57}$

Butir nilai keenam dari Sila Kedua Pancasila: "Menjunjung tinggi nilai-nilai kemanusiaan" 58 relevan dengan: QS.al-Isra' 70 : Allah swt dalam firman-Nya ini mengingatkan umat manusia akan kedudukan mereka yang dilebihkan atas makhluk Allah yang lainnya. ${ }^{59}$ Makanya dalam QS.al-Balad 11-16 Allah mengingkan dihapusnya perbudakan. Perbudakan bertentangan dengan prinsip kemanusiaan dimana Allah menciptakan manusia sebagai makhluk yang berkededukan tinggi di bumi ${ }^{60}$ Dari penafsiran di atas, jelaslah bahwa butir nilai keenam dari Sila kedua Pancasila juga sangat relevan dengan al-Quran Surat al-Balad ayat 11-16.

Butir nilai ketujuh dari Sila kedua Pancasila: "Gemar melakukan kegiatan kemanusiaan"61 relevan dengan QS.al-Isra' 26. Tentu yang Pancasila."

52 Kementerian Pertahanan, "45 Butir Pedoman Penghayatan Dan Pengamalan

${ }^{53}$ Al-Maraghi, Tafsir Al-Maraghi, 86.

${ }^{54}$ Al-Maraghi, 271. Pancasila."

55 Kementerian Pertahanan, "45 Butir Pedoman Penghayatan Dan Pengamalan

${ }^{56}$ Al-Maraghi, Tafsir Al-Maraghi, 128.

57 Al-Maraghi, 7. Pancasila."

${ }^{58}$ Kementerian Pertahanan, "45 Butir Pedoman Penghayatan Dan Pengamalan

${ }^{59}$ Ibnu Katsir, Tafsir Ibnu Katsir, 73.

${ }^{60}$ Shihab, Tafsir Al-Mishbah, Pesan, Kesan, Dan Keserasian Al-Quran Vol.15.

${ }^{61}$ Kementerian Pertahanan, "45 Butir Pedoman Penghayatan Dan Pengamalan Pancasila.” 
dimaksud pemberian disini tidak hanya materi, namun dapat juga hal-hal yang immateri. ${ }^{62}$ QS. Ali Imran 134. Calon-calon penghuni sorga ialah mereka yang menafkahkan hartanya dalam keadaan apapun, lapang maupun di waktu sempit, sakit atau sehat, malam maupun siang, secara sembunyi atau terangterangan. Mereka itu juga mempunyai mampu menahan amarah, tidak mudah terbawa oleh emosi dan mudah memaafkan kesalahan orang lain kepada mereka. ${ }^{63}$

Butir nilai kedelapan dari Sila kedua Pancasila: "Berani membela kebenaran dan keadilan" ${ }^{64}$ relevan dengan : QS.al-Anfal 15-16. Ancaman ini merupakan ancaman Allah terhadap orang mukmin yang akan melarikan diri dalam perang menghadapi orang kafi, dikecualikan jika lari ke belakang untuk memprkuat dan mempertahankan suatu barisan atau bergabung untuk siasat perang, sperti orang yang lari menuju kepada pimpinan panglimanya ${ }^{65}$ Dalam QS. an-Nisa' 58 Allah mewajibkan setiap orang berlaku adil dalam kedudukan apapun, baik sebagai pemimpin terhadap rakyat, ulama terhadap masyarakat biasa dan seterusnya. ${ }^{66}$

Butir nilai kesembilan dari Sila kedua Pancasil: "Bangsa Indonesia merasa dirinya sebagai bagian dari seluruh umat manusia" ${ }^{\circ 7}$ relevan dengan: QS.al-Baqarah 213. Allah telah memastikan bahwa umat manusia bagaikan umat yang satu, di mana antara satu dengan lainnya saling behubungan. ${ }^{68} \mathrm{QS}$. al-Hujarat 13 Allah memanggil semua manusia, bukan hanya orang beriman, lalu menjelaskan prinsip relasi antar manusia. ${ }^{69}$

Butir nilai kesepuluh dari Sila kedua Pancasila: "Mengembangkan sikap hormat menghormati dan bekerjasama dengan bangsa lain" ${ }^{\text {"70 }}$ relevan dengan QS.al-Hujarat 11. Ayat di atas memberi petunjuk agar tidak terjadi pertikaian, salah satunya dilarang mengolok-olok, sebaliknya menghormati

\footnotetext{
${ }^{62}$ Shihab, Tafsir Al-Mishbah, Pesan, Kesan, Dan Keserasian Al-Quran Vol.15, 449.

${ }^{63}$ Ibnu Katsir, Tafsir Ibnu Katsir, 200.

${ }^{64}$ Kementerian Pertahanan, "45 Butir Pedoman Penghayatan Dan Pengamalan Pancasila."

${ }^{65}$ Ibnu Katsir, Tafsir Ibnu Katsir, 577.

${ }^{66}$ Al-Maraghi, Tafsir Al-Maraghi, 116. Pancasila."

${ }^{67}$ Kementerian Pertahanan, "45 Butir Pedoman Penghayatan Dan Pengamalan

${ }^{68}$ Al-Maraghi, Tafsir Al-Maraghi, 212.

${ }^{69}$ Shihab, Tafsir Al-Mishbah, Pesan, Kesan Dan Keserasian Al-Quran Vol.12, 615.

${ }^{70}$ Kementerian Pertahanan, "45 Butir Pedoman Penghayatan Dan Pengamalan Pancasila.”
} 
siapapun menjadi hal penting. ${ }^{71}$ QS.at-Taubah 6: menjelaskan sikap menghormati orang lain meski ia berbeda keyakinan. Dalam Islam mereka diberi hak perlindungan nyawa, harta, dan juga keperecayaannya. ${ }^{72}$ Dari penafsiran di atas, jelaslah bahwa butir nilai kesepuluh dari Sila kedua Pancasila, juga sangat relevan dengan al-Quran Surat at-Taubah ayat 6.

\section{Sila Ketiga: Persatuan Indonesia}

Butir nilai kesatu dari Sila ketiga Pancasila : "Mampu menempatkan persatuan, kesatuan, serta kepentingan dan keselamatan bangsa dan negara sebagai kepentingan bersama di atas kepentingan pribadi dan golongan"73 relevan dengan; QS. Ali Imran ayat 103 menyerukan untuk bersatu, tidak bercerai berai, menghindari perselisihan. ${ }^{74}$ QS.al-Anbiya' ayat 92 menegaskan posisi Allah yang Maha Esa menjadi pemelihara dan pelindung semua umat manusia (ummah) ${ }^{75}$

Butir nilai kedua dari Sila ketiga ; "Sanggup dan rela berkorban untuk kepentingan negara dan bangsa apabila diperlukan" ${ }^{, 76}$ relevan dengan QS. alHasyr ayat 9. Pujian Allah tehadap kaum Anshar yang menghormati bahkan mengutamakan kaum Muhajirin diatas diri mereka sendiri ${ }^{77}$ QS. at-Taubah ayat 111: Allah menjanjikan surga bagi orang yang menggunakan harta bahkan jiwanya di jalan Allah, termasuk yang berkorban untuk bangsa dan negara. ${ }^{78}$

Butir nilai ketiga dari Sila ketiga: "Mengembangkan rasa cinta kepada tanah air dan bangsa relevan" ${ }^{\text {"79 }}$ dengan QS. al-Qashash ayat 85. Bahwa yang dimaksud dengan kata $M a^{\prime}$ 'ad dalam ayat tersebut adalah kota Makkah, sehingga ayat ini merupakan janji dari Allah bahwa Nabi Muhammad akan kembali ke Makkah (Tanah Air Tercinta) sebagai orang yang menang. ${ }^{80}$ QS.

\footnotetext{
${ }^{71}$ Shihab, Tafsir Al-Mishbah, Pesan, Kesan Dan Keserasian Al-Quran Vol.12, 605.

${ }^{72}$ Shihab, 22.

${ }^{73}$ Kementerian Pertahanan, "45 Butir Pedoman Penghayatan Dan Pengamalan Pancasila."

${ }^{74}$ Shihab, Tafsir Al-Mishbah, Pesan, Kesan Dan Keserasian Al-Quran Vol.12, 205.

${ }^{75}$ Shihab, 118.

${ }^{76}$ Kementerian Pertahanan, "45 Butir Pedoman Penghayatan Dan Pengamalan Pancasila."

${ }^{77}$ Al-Maraghi, Tafsir Al-Maraghi, 65.

${ }^{78}$ Ibnu Katsir, Tafsir Ibnu Katsir, 190.

79 Kementerian Pertahanan, "45 Butir Pedoman Penghayatan Dan Pengamalan Pancasila."

${ }^{80}$ Ibnu Katsir, Tafsir Ibnu Katsir, 190.
} 
an-Nisa ayat 66. Bani Israil disuruh keluar dari kampung halaman mereka ; dengan fiman Tuhan: Awikhruju min diyarikum; Atau keluarlah dari kampung halaman kalian dengan berhijrah ke negeri lain, Ma fa'aluhu (tidak mereka laksanakan). ${ }^{81}$

Butir nilai keempat dari Sila Ketiga Pancasila : "Mengembangkan rasa kebanggaan berkebangsaan dan bertanah air Indonesia" relevan dengan QS.al Hujurat 13 mengandung arti bahwa Allah menyatukan beragam suku bangsa dalam satu negara menghendaki mereka saling mengenal dan mencintai. ${ }^{82} \mathrm{QS}$. Ali Imran ayat 64 juga menegaskan untuk melakukan amal-amal yang Allah sukai, bersatu menegakkan kebaikan dan menolak segala hal yang memicu perselisihan. ${ }^{83}$

Butir nilai kelima dari Sila Ketiga Pancasila: "Memelihara ketertiban dunia yang berdasarkan kemerdekaan, perdamaian abadi dan keadilan sosial" ${ }^{84}$ relevan dengan QS. al-Baqarah ayat 126: Kemudian Nabi Ibrahim berdoa; "Ya Tuhanku, Jadikalah negei ini negeri yang aman." Yakni aman dari rasa takut, penduduknya tidak boleh ditakut-takuti oleh suatu apapun. ${ }^{85}$ QS. an-Nur ayat 55. Janji Allah kepadan Rasul-Nya bahwa Dia akan menjadikan umat Muhammad penguasa di atas bumi untuk menjadikan kehidupan aman dan nyaman bagi manusia. ${ }^{86}$

Butir nilai keenam dai Sila ketiga Pancasila: "Mengembangkan persatuan Indonesia atas dasar Bhinneka Tunggal Ika" ${ }^{87}$ relevan dengan QS.ar-Rum ayat 31-32 ajaran agama Islam yang disampaikan oleh Nabi Muhammad SAW dan yang merupakan agama yang telah dianaut dan diajarkan oleh Nabi Ibrahim AS, pada hakikatnya adalah agama yang mendambakan persatuan dan kesatuan umat manusia. ${ }^{88} \mathrm{QS}$. al-An'am ayat 153 ayat ini dan ayat an aqimuddina walaa tatafarraquu fihi, adalah perintah

${ }^{81}$ Al-Maraghi, Tafsir Al-Maraghi, 137-136.

${ }^{82}$ Shihab, Tafsir Al-Mishbah, Pesan, Kesan Dan Keserasian Al-Quran Vol.12, 62.

${ }^{83}$ Al-Maraghi, Tafsir Al-Maraghi, 309. Pancasila."

${ }^{84}$ Kementerian Pertahanan, "45 Butir Pedoman Penghayatan Dan Pengamalan

${ }^{85}$ Ibnu Katsir, Tafsir Ibnu Katsir, 243.

${ }^{86}$ Ibnu Katsir, 505.

${ }^{87}$ Kementerian Pertahanan, "45 Butir Pedoman Penghayatan Dan Pengamalan Pancasila."

${ }^{88}$ Shihab, Tafsir Al-Mishbah, Pesan, Kesan Dan Keserasian Al-Quran Vol.12. 
Allah untuk kaum mukminin menghindari perselisihan; ${ }^{89}$

Butir nilai ketujuh dari Sila ketiga Pancasila: "Memajukan pergaulan demi persatuan dan kesatuan bangsa" 90 relevan dengan QS. an-Nisa' ayat 59. Pada ayat ini Allah memberikan kaedah dalam berselisih untuk mencari solusinya pada al-Quran dan Hadist Nabi lalu menyepakati penyelesaian masalah yang ada. ${ }^{91}$ QS.Ali Imran ayat 103 : Bahwasanya persatuan adalah sesuatu yang sangat penting bagi manuisa untuk memiliki kekuatan yang besar dan tidak mudah dikalahkan. ${ }^{92}$

Sila Keempat: Kerakyatan yang Dipimpin oleh Hikmat Kebijaksanaan dalam Permusyawaratan Perwakilan

Butir nilai pertama dari Sila keempat Pancasila: "Sebagai warga negara dan warga masyarakat, setiap manusia Indonesia mempunyai kedudukan, hak dan kewajiban yang sama"93 relevan dengan QS.An-Nisa ayat 1. Ayat ini menjelaskan bahwa Allah memang sengaja menciptakan manusia berbedabeda, baik warna kulit, sifat, bahasa atau juga yang lainnya. ${ }^{94}$ QS. al-Hujarat ayat 13 menyatakan dengan tegas bahwa semua perbedaan manusia di hadapan Allah sama, tidak ada kelebihan satu dengan yang lainnya. ${ }^{95}$

Butir nilai kedua dari Sila keempat Pancasila: "Tidak boleh memaksakan kehendak kepada orang lain" ${ }^{96}$ relevan dengan QS. an-Nur ayat 33 : Di antara hukum-hukum yang tercakup dalam ayat ini, ialah larangan Allah memaksakan kehendak, bahkan kepada hamba sahaya (budak yang ia miliki) wanita sekalipun. Allah melarang memaksakan mereka melacurkan diri, untuk mencari keuntungan dan memperoleh penghasilan dari pelacuran mereka itu. ${ }^{97}$ QS. al-Baqarah ayat 256 : menyatakan tidak ada paksaan dalam hal keimanan (agama). Agama dan iman harus dengan ketaatan dan ketundukan yang sudah tentu tidak dapat dibentuk dengan paksa, ia hanya dapat diterima oleh akal melalui alasan yang kuat. ${ }^{98}$

\footnotetext{
${ }^{89}$ Ibnu Katsir, Tafsir Ibnu Katsir, 369.

90 Kementerian Pertahanan, "45 Butir Pedoman Penghayatan Dan Pengamalan Pancasila."

${ }^{91}$ Al-Maraghi, Tafsir Al-Maraghi, 120.

${ }^{92}$ Hamka, Tafsir Al-Azhar Juz 1 (Singapura: Kerjaya print, 2007), 27.

93 Kementerian Pertahanan, "45 Butir Pedoman Penghayatan Dan Pengamalan Pancasila."

${ }^{94}$ Ibnu Katsir, Tafsir Ibnu Katsir, 308.

${ }^{95}$ Ibnu Katsir, 361.

96 Kementerian Pertahanan, "45 Butir Pedoman Penghayatan Dan Pengamalan Pancasila."

${ }^{97}$ Ibnu Katsir, Tafsir Ibnu Katsir, 491-490.

${ }^{98}$ Al-Maraghi, Tafsir Al-Maraghi, 31.
} 
Butir nilai ketiga dari Sila keempat Pancasila: "Mengutamakan musyawarah dalam mengambil keputusan untuk kepentingan bersama" 99 relevan dengan QS. Ali Imran ayat 159. Pada ayat ini jelas Allah meninggikan musyawarah. Allah meminta Nabi memaafkan orang-orang yang menentangnya, meminta ampunan bagi mereka lalu mengajak mereka bermusyawarah dalam berbagai perkara. ${ }^{100}$ QS. as-Syura ayat 38 Ayat ini memerintahkan 3 hal penting yakni membangun hubungan dengan Tuhan melalui sholat dan hubungan dengan manusia dengan musyawarah serta berbagi rezeki yang Allah anugerahkan. ${ }^{101}$

Butir nilai keempat dari Sila keempat Pancasila: "Musyawarah untuk mencapai mufakat diliputi oleh semangat kekeluargaan" "102 relevan dengan QS. al-Baqarah ayat 233. Ayat ini menjadi mengandung dalil kebolehan berijtihad dalam hukum. Dasarnya adalah dibolehkannya oleh Allah orang tua bersmuyswarah dengan anaknya. Bermusyawarah dalam mencari pilihan terbaik untuk kebaikan bersama. ${ }^{103}$

Butir nilai kelima dari Sila keempat Pancasila: "Menghormati dan menjunjung tinggi setiap keputusan yang dicapai sebagai hasil musyawarah"104 relevan dengan QS. as-Syura ayat 38. Allah memberi pujian kepada mereka yang bermusyawarah untuk membela Nabi yakni kaum Anshor di rumah Abu Ayyub Al-Anshari. Artinya segala musyawarah yang dilakukan untuk kebaikan mendapat pujian dari Allah. ${ }^{105}$ QS. Ali Imran ayat 159 menegaskan bila sudah bermusyawarah maka hendaklah bertekad untuk melaksanakannya, Allah menyukai orang-orang yang bermusyawarah dan menyerahkan diri kepadaNya untuk itu. ${ }^{106}$

Butir nilai keenam dari Sila Keempat Pancasila: “Dengan i'tikad baik dan rasa tanggung jawab menerima dan melaksanakan hasil keputusan Pancasila."

${ }^{99}$ Kementerian Pertahanan, "45 Butir Pedoman Penghayatan Dan Pengamalan

${ }^{100}$ Al-Qurthubi, Tafsir Al-Qurthubi Jilid 3 (Jakarta: Pustaka Azzam, 2007), 628622.

${ }^{101}$ Shihab, Tafsir Al-Mishbah, Pesan, Kesan Dan Keserasian Al-Quran Vol.12, 513511. Pancasila."

102 Kementerian Pertahanan, “45 Butir Pedoman Penghayatan Dan Pengamalan

${ }^{103}$ Hamka, Tafsir Al-Azhar Juz 1, 562.

Pancasila."

104 Kementerian Pertahanan, "45 Butir Pedoman Penghayatan Dan Pengamalan

${ }^{105}$ M. Quraish Shihab, Wawasan Al-Quran: Tafsir Tematik Atas Pelbagai Persoalan Umat (Badung: Mizan, 1944), 619.

${ }^{106}$ Shihab, 314. 
musyawarah"107 relevan dengan QS. an-Nisa' ayat 59. Ayat ini menegaskan i'tikad baik berdasarkan pada nilai-nilai Quran dan Sunnah dapat menjadi petunjuk menuju kebenaran dalam musyawarah. ${ }^{108}$ QS. al-Mujadilah ayat 9 memberi tuntunan kepada orang-orang beriman untuk tidak bermusyawarah dalam merencanakan hal-hal yang membuat dosa. Merencanakan tindakan dosa termasuk dalam perbuatan orang yang berpenyakit hatinya. ${ }^{109}$

Butir nilai ketujuh dari Sila keempat Pancasila: "Di dalam musyawarah diutamakan kepentingan bersama di atas kepentingan pribadi dan golongan" 110 relevan dengan QS. an-Nisa' ayat 59, Allah menegaskan jika tidak ditemukan dalil Quran dan Sunnah maka nilai-nilai dan jiwa yang bersandar pada dua pegangan tersebut. ${ }^{111} \mathrm{QS}$. as-Syura ayat 38 Allah melarang sikap otoriter, menekankan prinsip musyawarah dalam melahirkan kebaikan bersama. ${ }^{12}$

Butir nilai yang kedelapan dari Sila keempat Pancasila: "Musyawarah dilakukan dengan akal sehat dan sesuai dengan hati nurani yang luhur"113 relevan dengan QS. Ali Imran ayat 159. Ayat ini mencakup beberapa pilar kesuksesan dakwah nabawi, diantaranya adalah muasyawarah. Musyawarah merupakan salah satu kaedah syar'iyah dan ketentuan hukum. Barang siapa tidak meminta pendapat kepada ahli ilmu dan agama, maka mengucilkannya adalah wajib. ${ }^{114}$

Butir nilai kesembilan dai Sila keempat Pancasila: "Keputusan yang diambil harus dapat dipertanggungjawabkan secara moral kepada Tuhan Yang Maha Esa, menjunjung tinggi harkat dan martabat manusia, nilai-nilai kebenaran dan keadilan mengutamakan persatuan dan kesatuan demi kepentingan bersama" relevan dengan QS. an-Nisa' ayat 59. Selain itu, pada QS. Ali Imran ayat 103 Allah mengingatkan bahwa persatuan adalah kekuatan yang besar. ${ }^{115}$

Butir nilai kesepuluh dari Sila Keempat Pancasila: "Memberikan Pancasila."

107 Kementerian Pertahanan, "45 Butir Pedoman Penghayatan Dan Pengamalan

${ }^{108}$ Shihab, Wawasan Al-Quran: Tafsir Tematik Atas Pelbagai Persoalan Umat, 581.

${ }^{109}$ Shihab, 486.

Pancasila."

${ }^{110}$ Kementerian Pertahanan, "45 Butir Pedoman Penghayatan Dan Pengamalan

${ }^{111}$ Shihab, Wawasan Al-Quran: Tafsir Tematik Atas Pelbagai Persoalan Umat, 584.

${ }^{112}$ Shihab, Tafsir Al-Mishbah, Pesan, Kesan Dan Keserasian Al-Quran Vol.12, 513-

511.

113 Kementerian Pertahanan, "45 Butir Pedoman Penghayatan Dan Pengamalan Pancasila."

${ }^{114}$ Wahbah Az-Zuhaili, Tafsir Al-Wasith (Jakarta: Gema Insani, 2012), 229.

${ }^{115}$ Hamka, Tafsir Al-Azhar Juz 1, 584. 
kepercayaan kepada wakil-wakil yang dipercayai untuk melaksanakan pemusyawaratan" $" 116$ relevan dengan QS. Shad ayat 26. Allah mengingatkan setiap yang mendapatkan kepercayaan untuk memimpin agar dapat mendengarkan aspirasi dari masyarakat atau siapun yang memberikan amanah. ${ }^{117}$ Nilai ini juga relevan dengan QS. as-Syura ayat 38. ${ }^{118}$

\section{Sila Kelima: Keadilan Sosial Bagi Seluruh Rakyat Indonesia}

Butir nilai pertama dari Sila kelima Pancasila: "Mengembangkan perbuatan yang luhur, yang mencerminkan sikap dan suasana kekeluargaan dan kegotong royongan" 119 relevan dengan QS. An-Nahl ayat 90. Disini Allah memerintahkan siapapun untuk berlaku adil dalam sikap, ucapan dan tindakan, Hal ini termasuk prilaku ihsan di mata Allah. ${ }^{120}$ QS. al-Maidah ayat 2 menjadi dalil untuk saling tolong menolong dalam segala hal baik tanpa memandang keyakinan sekalipun. ${ }^{121}$

Butir nilai kedua dari Sila kelima Pancasila: "Mengembangkan sikap adil terhadap sesama"122 relevan dengan QS. an-Nisa' ayat 58. Pada ayat ini jelas Allah memerintahkan untuk berlaku amanah. Menjaga apapun yang diamanahkan sebaik-baiknya, termasuk rahasia yang dipercayakan. ${ }^{123}$ QS. an-

Nahl ayat 90 penegasan akan pentingnya sikap wasath, adil dan ihsan. ${ }^{124}$ Ini termasuk sikap yang terus dikampanyekan oleh kementerian Agama Republik Indonesia.

Butir nilai ketiga dari Sila kelima Pancasila: "Menjaga keseimbangan antara hak dan kewajiban"125 relevan dengan QS.al-Baqarah ayat 233. Salah satu kewajiban bagi suami adalah memenuhi kebutuhan keluarganya yakni memberi makan dan pakaian. Namun kewajiban tersebut sesuai dengan kadarnya, dengan prinsip ma'ruf. ${ }^{126}$ QS. an-Nisa' ayat 129 memerintahkan berlaku adil suami termasuk terhadap istri-istrinya. Tidak boleh terlalu Pancasila."

${ }^{116}$ Kementerian Pertahanan, "45 Butir Pedoman Penghayatan Dan Pengamalan

${ }^{117}$ Hamka, Tafsir Al-Azhar Juz 4 (Jakarta: Pustaka Panjimas, 1984), 27.

${ }^{118}$ Shihab, Tafsir Al-Mishbah, Pesan, Kesan Dan Keserasian Al-Quran Vol.12, 370. Pancasila."

119 Kementerian Pertahanan, "45 Butir Pedoman Penghayatan Dan Pengamalan

${ }^{120}$ Shihab, Wawasan Al-Quran: Tafsir Tematik Atas Pelbagai Persoalan Umat, 697.

${ }^{121}$ Shihab, 13.

Pancasila."

${ }^{122}$ Kementerian Pertahanan, "45 Butir Pedoman Penghayatan Dan Pengamalan

${ }^{123}$ Abdul Halim Hasan, Tafsir Al-Ahkam (Jakarta: Kencana, 2011), 283-282.

${ }^{124}$ Ar Rifa ${ }^{e c i}$, Ringkasan Tafsir Ibnu Katsir, 1056.

Pancasila."

${ }^{125}$ Kementerian Pertahanan, "45 Butir Pedoman Penghayatan Dan Pengamalan

${ }^{126}$ Shihab, Membumikan Al-Quran. Fungsi Dan Peran Wahyu Dalam Kehidupan Masyarakat, 610. 
cenderung pada salah satu diantara mereka, harus berlaku adil secara materi. ${ }^{127}$

Butir nilai keempat dari Sila kelima Pancasila: "menghormati hak orang lain" 128 relevan dengan QS. asy-Syu'ara ayat 183. Ayat ini melarang bertindak yang merugikan orang lain, salah satunya dilarang mengurangi kadar atau nilai dari barang orang lain tanpa hak. ${ }^{129}$ QS. al-Hajj ayat 39 memperjelaskan izin perang dalam Islam saat berada pada posisi teraniaya, artinya dalam konteks membela diri. ${ }^{130}$

Butir nilai kelima dari Sila kelima Pancasila: "Suka memberi pertolongan kepada orang lain agar dapat berdiri sendiri" 131 relevan dengan QS.at-Taubah ayat 40. Allah mempertegas bahwa Ia akan selalu menjadi penolong Nabi, manusia agung yang selalu berbuat baik meskipun ada yang enggan menolongnya. ${ }^{132}$ QS.al-Anfal ayat 72 mewajibkan bagi setiap muslim untuk membela orang-orang yang dipaksa keluar dari agamanya, atau mengganggu kebebasan beragama. ${ }^{133}$

Butir nilai keenam dari Sila kelima Pancasila: "Tidak menggunakan hak milik untuk usaha-usaha yang bersifat pemerasan terhadap orang lain"134 relevan dengan QS.al-Baqarah ayat 188. Ayat ini melarang mengambil milik orang lain tanpa hak. Selain itu, batil bagi orang yang menggunakan instrumen hukum untuk mengambil harta yang sesungguhnya bukan miliknya. ${ }^{135} \mathrm{QS}$. anNisa' ayat 161 larangan memakan riba karena melanggar prinsip kemanusiaan. Artinya melakukan riba adalah melanggar kemanusian sekaligus melanggar larangan Tuhan. ${ }^{136}$

Butir nilai ketujuh dari Sila kelima Pancasila: "Tidak menggunakan hak milik untuk hal-hal yang bersifat pemborosan dan gaya hidup mewah"137

${ }^{129}$ Shihab, Membumikan Al-Quran. Fungsi Dan Peran Wahyu Dalam Kehidupan

${ }^{127}$ Shihab, 743. Masyarakat, 330.

${ }^{130}$ Shihab, 218.

Pancasila."

${ }^{131}$ Kementerian Pertahanan, "45 Butir Pedoman Penghayatan Dan Pengamalan

${ }^{132}$ Shihab, Membumikan Al-Quran. Fungsi Dan Peran Wahyu Dalam Kehidupan Masyarakat, 104.

${ }^{133}$ Shihab, 616.

Pancasila."

${ }^{134}$ Kementerian Pertahanan, "45 Butir Pedoman Penghayatan Dan Pengamalan

${ }^{135}$ Shihab, Membumikan Al-Quran. Fungsi Dan Peran Wahyu Dalam Kehidupan Masyarakat, 499.

${ }^{136}$ Shihab, 807.

137 Kementerian Pertahanan, "45 Butir Pedoman Penghayatan Dan Pengamalan Pancasila." 
relevan dengan : QS.al-Isra' ayat 26-27 . Ayat ini melarang berlaku boros, karena dengan dilarangnya boros tersebut akan bisa diperbaiki keadaan seseorang dan tidaklah menjadi kacau penghidupannya, sedang kebaikan keadaan seseorang, berarti memperbaiki pula umat seluruhnya. ${ }^{138}$ QS. al-A'raf ayat 31 melarang berlebih-lebihan termasuk dalam hal makan minum, Allah tidak menyukai hal ini. ${ }^{139}$

Butir nilai kedelapan dari Sila kelima Pancasila: "Tidak menggunakan hak milik untuk bertentangan dengan atau merugikan kepentingan umum"140 relevan dengan QS. al-Baqarah ayat 11: Larangan di sini ditujukan kepada hal-hal yang akan mengakibatkan kerusakan, yaitu di dalam membuka rahasia umat Islam kepada kaum kafir. Kemudian menyuruh kaum kafir itu agar membujuk umat Islam supaya jangan mengikuti ajaran Nabi Muhammad saw. ${ }^{141}$ QS. al-Maidah ayat 38 Allah menegaskan larangan tindakan pencurian apapun. ${ }^{142}$

Butir nilai kesembilan dari Sila kelima Pancasila: "Suka bekerja keras relevan"143 dengan QS. an-Nahl ayat 97. Allah berfirman memberi janji balasan bagi setiap kebiakan atau amal sholeh. ${ }^{144}$ QS. Fusshilat ayat 5 : Ucapan mereka : Bekerjalah sesungguhnya kami pun akan bekerja; ada juga yang memahaminya dalam arti "Lakukanlah apa yang hendak engkau lakukan, untuk menghalang kami, kamipun akan melakukan hal yang sama", atau beramallah sesuai ajaran agama kamu, kami pun akan melaksanakan ajaran agama kami. ${ }^{145}$

Butir nilai kesepuluh dari Sila kelima Pancasila: "Suka menghargai hasil karya orang lain yang bermanfaat bagi kemajuan dan kesejahteraan bersama" 146 relevan dengan QS. Saba' ayat 13. Di ayat ini Allah menceritakan (artinya menghargai) jin-jin bekerja membangun gedunggedung untuk dipersembahkan kepada nabi Sulaiman sebagai bentengbenteng atau tempat peribadatan. ${ }^{147}$ QS. al-Insyirah ayat 5-7 memerintahkan untuk setiap pribadi tidak menyia-nyiakan waktu, bekerja menyelesaikan

\footnotetext{
138

${ }^{139}$ Al-Maraghi, Tafsir Al-Maraghi, 236.

140 Kementerian Pertahanan, "45 Butir Pedoman Penghayatan Dan Pengamalan Pancasila."

${ }^{141}$ Al-Maraghi, Tafsir Al-Maraghi, 84.

${ }^{142}$ Ibnu Katsir, Tafsir Ibnu Katsir, 96.

${ }^{143}$ Kementerian Pertahanan, "45 Butir Pedoman Penghayatan Dan Pengamalan Pancasila."

${ }^{144}$ Ibnu Katsir, Tafsir Ibnu Katsir, 640.

${ }^{145}$ Shihab, Tafsir Al-Mishbah, Pesan, Kesan Dan Keserasian Al-Quran Vol.12, 12. Pancasila."

${ }^{146}$ Kementerian Pertahanan, "45 Butir Pedoman Penghayatan Dan Pengamalan

${ }^{147}$ Shihab, Tafsir Al-Mishbah, Pesan, Kesan Dan Keserasian Al-Quran Vol.12, 582.
} 
tugasnya lalu melanjutkan pekerjaan yang lainya. ${ }^{148}$

Butir nilai kesebelas dari Sila kelima Pancasila: "Suka melakukan kegiatan dalam rangka mewujudkan kemajuan yang merata dan berkeadilan sosial" 149 relevan dengan QS.al-Isra' ayat 29. Allah berfiman memerintahkan hamba-Nya untuk bertindak adil (wasath), tidak berada pada kebakhilan dan tidak pula pada kemubaziran. ${ }^{150} \mathrm{QS}$. an-Nisa' ayat 135 tegas mengutamakan tindakan dibandingkan ucapan, tindakan lebih bermakna. ${ }^{151}$

\section{Kesimpulan}

Dari sepanjang bahasan terdahulu, terutama yang berkaitan dengan pemasalahan utama yang tersirat dalam pertanyaan penelitian ini, maka dapat disimpulkan bahwa hubungan butir-butir nilai Pancasila dengan ayat-ayat AlQuran, adalah dalam bentuk makna dan maksud yang terkandung di dalam butir-butir nilai Pancasila, sama dengan makna dan maksud yang dikandung oleh ayat-ayat Al-Quran. Dalam artian bahwa makna dan maksud dari butirbutir nilai Pancasila yang berjumlah empat puluh lima butir tersebut, tidak bertentangan dengan makna dan maksud dari ayat-ayat Al-Quran.

Persepsi Al-Quran terhadap butir-butir nilai Pancasila, dapat dilihat dari hasil analisis tafsir ayat-ayat Al-Quran yang relevan dengan butir-butir nilai Pancasila, di mana diketahui dengan jelas bahwa persepsi Al-Quran terhadap butir-butir nilai Pancasila, secara umum dan prinsip merupakan sebagian kecil dari ajaran Islam yang dikandung oleh Al-Quran. Dengan kata lain keempat puluh lima butir nilai Pancasila tersebut makna dan maksudnya telah tekandung di dalam Al-Quran baik secara nyata maupun secara tersirat.

\section{Daftar Pustaka}

Adhayanto, Oksep. "Implementasi Nilai-Nilai Pancasila Sebagai Dasar Negara Dalam Pembentukkan Peraturan Perundang-Undangan." Jurnal Ilmu Hukum. Vol. 2015. https://jih.ejournal.unri.ac.id/index.php/JIH/article/view/3599.

Al-Farmawi, Abd.Al-Hayy. Metode Tafsir Maudhu'iyy; Suatu Pengantar. Jakarta: Raja Grafindo Persada, 1996.

Al-Maraghi, Ahmad Mushthafa. Tafsir Al-Maraghi. Semarang: Karya Thoha Putra, 1993.

${ }^{148}$ Shihab, 421.

149 Kementerian Pertahanan, "45 Butir Pedoman Penghayatan Dan Pengamalan Pancasila."

${ }^{150}$ Ibnu Katsir, Tafsir Ibnu Katsir, 38.

${ }^{151}$ Shihab, Membumikan Al-Quran. Fungsi Dan Peran Wahyu Dalam Kehidupan Masyarakat, 264. 
194 | FOKUS : Jurnal Kajian Keislaman dan Kemasyarakatan Vol. 5, No. 2, 2020

Al-Qurthubi. Tafsir Al-Qurthubi Jilid 3. Jakarta: Pustaka Azzam, 2007.

Al-Suyûthî, Jalâl al-Din. Al-Itqân Fî 'Ulûm Al-Qur'ân. Kairo: Dâr al-Turâth, 1985.

Ar Rifaei, Muhammad Nasib. Ringkasan Tafsir Ibnu Katsir. Jakarta: Gema Insani Press, 1999.

Az-Zuhaili, Wahbah. Tafsir Al-Wasith. Jakarta: Gema Insani, 2012.

Baidan, Nashruddin. Metodologi Penafsiran Al-Qur'an. Jakarta: Pustaka Pelajar, 1988.

. Metodologi Penafsiran Al-Quran. Jakarta: Pustaka Pelajar, 1988.

Basuki, Udiyo. "Politik Hukum Mahkamah Konstitusi Dalam Membatalkan Konsep Empat Pilar Sebagai Upaya Mendudukkan Pancasila Sebagai Dasar Negara." Supremasi Hukum: Jurnal Kajian Ilmu Hukum. Vol. 4, $2015 . \quad$ http://ejournal.uinsuka.ac.id/syariah/Supremasi/article/download/1993/1469.

BPHN. "Butir-Butir Pancasila." Badan Pembinaan Hukum Nasional, 2014. bphn.go.id > data > documents > butir-butir_pancasila_1\%0A.

Dewi, Septiana Chandra. "Upaya BNPT Dalam Menghadapi Ancaman Keamanan Dari Kelompok Radikal Isis (Islamic State Of Iraq And Syria).” EJournal Ilmu Hubungan Internasional 6, no. 1 (2018): 31328. www.m.republika.co.id:2014.

Farih, Amin. "Konsistensi Nahdlatul Ulama'dalam Mempertahankan Pancasila Dan Kedaulatan Negara Kesatuan Republik Indonesia Di Tengah Wacana Negara Islam." Jurnal Politik Walisongo, 2019. https://core.ac.uk/download/pdf/267896206.pdf.

Gesmi, and Hendri. Buku Ajar Pendidikan Pancasila. Ponorogo: Uwais Inspirasi Indonesia, 2018.

Gumilang, Prima. "Kepala BIN: HTI Ingin Ganti Pancasila Jadi Khilafah." CNN Indonesia. May 2017. https://www.cnnindonesia.com/nasional/20170512135522-12214314/kepala-bin-hti-ingin-ganti-pancasila-jadi-khilafah.

Hamka. Tafsir Al-Azhar Juz 1. Singapura: Kerjaya print, 2007.

—. Tafsir Al-Azhar Juz 4. Jakarta: Pustaka Panjimas, 1984.

Hasan, Abdul Halim. Tafsir Al-Ahkam. Jakarta: Kencana, 2011. 
Hasibuan, Afriadi S, and Djoko Sulistyono. "Peranan Ideologi Dalam Integrasi Nasional." Jurnal Kebijakan Pemerintahan 1, no. 1 (2018): 1-10. http://ejournal.ipdn.ac.id/JKP/article/view/1093/633.

Ibnu Katsir. Tafsir Ibnu Katsir. Surabaya: Bina Ilmu, 2006.

Izzan, Ahmad. Metodologi Ilmu Tafsir. Tafakur, n.d.

Karim, M. Abdul. Menggali Muatan Pancasila Dalam Prespektif Islam. Yogyakarta: Surya Raya, 2004.

Kementerian Pertahanan. "45 Butir Pedoman Penghayatan Dan Pengamalan Pancasila." Direktorat Jenderal Perencanaan Pertahanan Kementerian Pertahanan Republik Indonesia, 2014. https://www.kemhan.go.id/renhan/2014/11/20/45-butir-pedomanpenghayatan-dan-pengamalan-pancasila.html.

Mardliyah, Hayati. "Dakwah Multikultural Kh. Ahmad Mustofa Bisri (Gus Mus)", Skripsi, Semarang, 2018. http://eprints.walisongo.ac.id/8484/.

Misrawi, Zuhairi. Al-Quran Kitab Toleransi, Inklusivisme, Pluralisme Dan Multikulturalisme. Jakarta: Fitrah, 2007.

Moh. Nadlir. "Mendagri: Masih Ada Ormas Dan Perorangan Yang Ingin Ganti Pancasila." Kompas. October 18, 2017. https://nasional.kompas.com/read/2017/10/18/11051731/mendagrimasih-ada-ormas-dan-perorangan-yang-ingin-gantipancasila?page $=$ all.

Mulyono. "Pancasila Sebagai Orthodoksi Dan Orthopraksis Dalam Kehidupan Berbangsa Dan Bernegara." HUMANIKA 23, no. 2 (2016): 40-48.

Munawir, Ahmad Warson. Kamus Al-Munawir Arab-Indonesia Terlengkap. Surabaya: Progresif, 2002.

Rohimin. Metodologi Ilmu Tafsir Dan Aplikasi Model Penafsiran. Yogyakarta: Pustaka Pelajar, 2007.

Shihab, M. Quraish. Membumikan Al-Quran. Fungsi Dan Peran Wahyu Dalam Kehidupan Masyarakat. Bandung: Mizan, 2007.

. Tafsir Al-Mishbah, Pesan, Kesan, Dan Keserasian Al-Quran Vol.15. Jakarta: Lentera, 2002.

. Tafsir Al-Mishbah, Pesan, Kesan, Dan Keserasian Al-Quran Vol.5. Jakarta: Lentera, 2002.

. Tafsir Al-Mishbah, Pesan, Kesan Dan Keserasian Al-Quran Vol.12. Jakarta: Lentera Hati, 2002. 
. Wawasan Al-Quran: Tafsir Tematik Atas Pelbagai Persoalan Umat. Badung: Mizan, 1944.

"Sudarto, Refleksi Metafisik Atas Pancasila, Dalam Jurnal Teologia Penelusuran Google." Jurnal Filsafat, 1996, 1-13. https://jurnal.ugm.ac.id/wisdom/article/view/31615/19139.

Sugini. Metode Penelitian Kuantitatif, Kualitatif Dan R\&D. Bandung: Alfabeta, 2008.

Sulasmono, B.S. Dasar Negara Pancasila. Sleman: Kanisius, 2015.

Suryatni. "Pancasila Sebagai Ideologi Negara Dan Hak Asasi Manusia Dalam Menjaga Keutuhan Negara Kesatuan Republik Indonesia." Jurnal Ilmiah Hukum Dirgantara, 2018, 1-18. https://core.ac.uk/download/pdf/288339901.pdf.

Tagel Eddy, Wayan. "Aktualisasi Nilai Pancasila Dalam Kehidupan Berbangsa Dan Bernegara." Dharmasmrti Nomor. Vol. 18. Accessed August 21, 2020.

http://ejournal.unhi.ac.id/index.php/dharmasmrti/article/view/108.

Tome, Abdul Hamid. "Evaluasi Norma Kedaulatan Rakyat Dalam Konstitusi Dan Pelaksanaannya Dalam Kerangka Negara Hukum Demoratis." Jurnal.Umt.Ac.Id. Accessed August 21, 2020. https://doi.org/10.31332/aladl.v13i1.1717.

- "Membumikan Pancasila: Upaya Pelembagaan Nilai Pancasila Dalam Kehidupan Masyarakat Desa." Researchgate.Net. Accessed August 21, 2020. https://doi.org/10.31332/aladl.v13i1.1717.

Usman. Ilmu Tafsir. Yogyakarta: Teras, 2009.

Wahyudi, Chafid. "Realitas Civil Religion Realitas Civil Religion Dalam Pergulatan Politik Islam Indonesia." Proceeldings.Kopertais4.or.Id, 2019.

http://proceedings.kopertais4.or.id/index.php/ancoms/article/view/24 3.

Warsah, I., Y. Masduki, Imron, M. Daheri, and R. Morganna. "Muslim Minority in Yogyakarta: Between Social Relationship and Religious Motivation." Qudus International Journal of Islamic Studies 7, no. 2 (2019). https://doi.org/10.21043/qijis.v7i2.6873. 